\title{
Socio-semiotics and the symbiosis of humans, horses, and objects in later Iron Age Britain.
}

\author{
Caroline Pudney
}

Department of History and Archaeology, University of Chester, UK.

University of Chester, Parkgate Road, Chester, CH1 4BJ. (c.pudney@ chester.ac.uk)

\begin{abstract}
Using an approach derived from material culture studies and semiotics, this paper addresses possible relationships between humans and horses in the British Iron Age. Through a study of the dominance of horse imagery found on Iron Age British coinage, specifically the Western coinage traditionally attributed to the 'Dobunni', the author explores how it may reflect possible relationships between humans and horses and their personhood therein. Drawing on wider faunal and metalwork evidence it is argued that these coins could be interpreted as a manifestation of the complex perspectives surrounding a symbiotic relationship between humans and horses.
\end{abstract}

Keywords: Iron Age; coins; horses; personhood; semiotics

\section{Introduction}

The coinage traditionally ascribed to the Dobunni in later Iron Age Britain is particularly marked in the dominance of human and horse imagery upon opposing faces. This begs the questions as to how this has come to be and what significance the human head and horse held in Iron Age worlds. In order to answer this we must consider the coins themselves as well as the evidence for human-horse relationships from the area in which these coins were created and predominately used. British Western Iron Age coinage is mostly geographically ascribed to the traditional English counties of Gloucestershire, north Somerset, north and west Wiltshire, Oxfordshire, and Worcestershire, based upon the distribution of find spots (Hobbs 1996, 25 and Figure 
1). The coinage is produced between c. $35 \mathrm{BC}$ and the $\mathrm{AD} 40 \mathrm{~s}$, at what is generally perceived as the end of the Iron Age in England and Wales. In many instances, the archaeological evidence supports the continued use and deposition of these coins into the post-conquest period. In this article the coins are being argued as materialisations of existing and perhaps mythologised human-horse-object relationships. Contextual archaeological evidence is thus taken more broadly from the later prehistoric period in western Britain (c. 800 BC onwards).

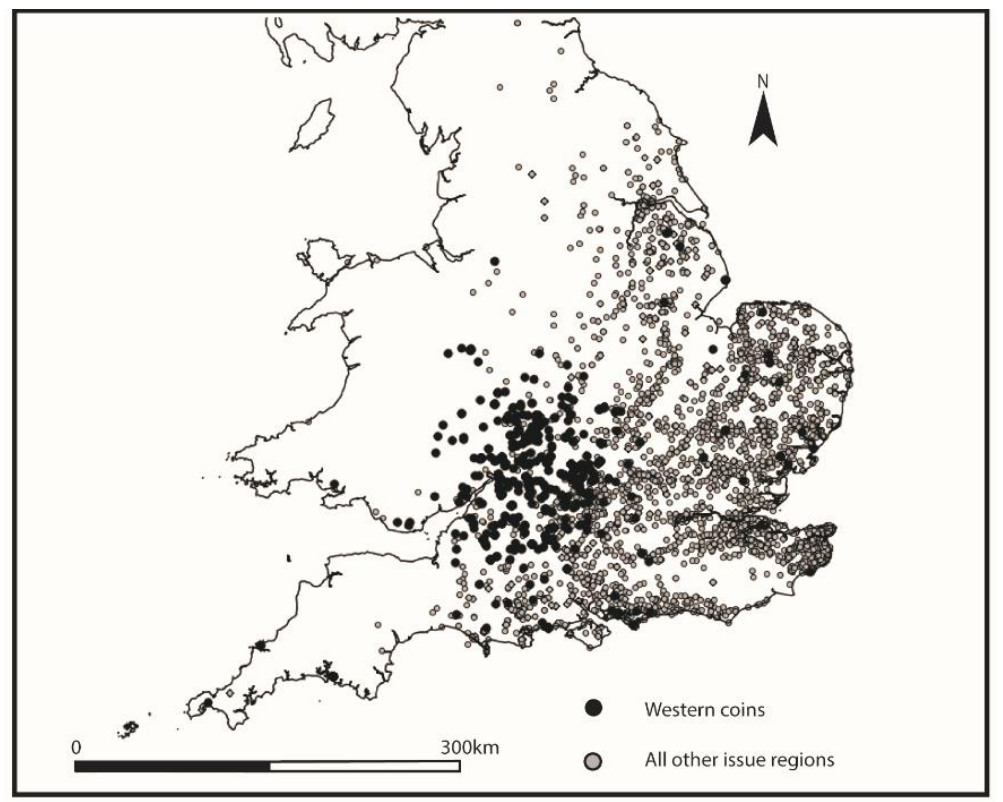

Figure 1: Core zone of Western coinage based upon distributions of find spots. Data derives from the Celtic Coin Index and PAS collections, and relates to all recorded Western coinage with spatial data therein

Traditionally, Iron Age coins have not been approached within frameworks of material culture studies, instead usually being disconnected from them within the oftenseparate field of numismatics (Kemmers \& Nanouschka 2011). Through examination of Western coinage as featured in the Celtic Coin Index (CCI) (www.celticcoins.ca) and as more recently incorporated into the Portable Antiquities Scheme (PAS) database 
(www.finds.org.uk), the author explores the imagery on the coins and addresses their cultural values and social roles. This paper therefore moves beyond existing analyses and interpretations of Iron Age coins, specifically British Western coinage.

Firstly, the dominance of horse imagery on Western coins will be discussed and secondly, specific assemblages of faunal remains and other horse-related metalwork will be drawn upon to tease out possible layers of significance within human-objectanimal relationships. Since the evidence for specific Iron Age beliefs is scarce the details of how Iron Age peoples understood their material and spirit worlds and maintained connections between them is difficult to establish. Yet evidence for the treatment of objects and animals in daily life and more periodic activity suggests a multi-layered relationship between people, animals, and objects that was embodied through complex performances.

Iron Age societies have been argued as animistic (Aldhouse-Green 2000; 2004; Oswald 1997), a suggestion that is supported by the evidence for late Iron Age sacred sites, which tend to focus around natural places such as springs, rivers, and woodland groves. Examples can be found across Britain such as at Uley Bury (Woodward \& Leach 1993), and Hayling Island (King \& Soffe 1994), where evidence for later Iron Age ritual structures and votive deposits have been found preserved underneath subsequent Romano-Celtic temples. Iron Age societies in Britain have also been argued as totemic (Green 1996; Parker Pearson 1999). In the former, aspects of personhood are brought to animals, plants, rocks, rivers and so on (Gosden 2012). In totemism, however, an animal can be emblematic so that then people may share characteristics of behaviour or inclination with that species (Gosden 2012). In either circumstance, animals, plants, the earth and sky could have been considered to contain spirits and divine entities with which a rapport might be established. In such societies animals 
possessed sanctity and symbolism. Many animist and totemist societies therefore also consider aspects of the human-made, material world to be animate, where particular objects possess an agency and potency of their own (Ingold 2007). For example, it has been surmised that in many prehistoric and contemporary societies, metalwork can be born, live, and die (Budd and Taylor 1995; Giles 2007; Hingley 1997), and thus be considered a person. If this is the case, objects such as coins may also have been considered as having spirits by their Iron Age creators, especially since these small, metal discs are literally transformed from the earth, which itself was possibly considered sentient in some way. The concept of the person is therefore also often different, where a person can be made up of a variety of elements; human and other (Fowler 2005). The person can thus be viewed as a dividual, the essences of which are fluid and can be permeable, partible, transformed, and fragmented (Fowler 2005). Dividuals can also therefore become enchained (Chapman 2013).

Many studies of animistic societies suggest that conceptions of spirits subsist in the flow of the activity itself (Ingold 2000, 162). Concepts of spirits are thus not merely expressed in activity but come into being through performance (Willerslev 2007, 156). These performances would include, but are not limited to the creation of the object, its use in everyday or more specialised practices and also perhaps, its intentional deposition or discard. The author argues that the horse imagery on British Western coinage is created within this interactive network. The powerful associations of the horse and of metalworking in regional Iron Age societies comes to be viewed as an integral fragment of personhood.

\section{Western coinage in context}

Initially taking inspiration from Southern coinage, the Western coinage, together with other peripheral issue regions (South-Western and East Anglian), largely followed 
its own innovative developments. Western coinage is marked by its design, often demonstrating complex progressions over relatively short periods of time and, as already mentioned, also by its distribution (figure 1). The result of this is that exact chronologies are difficult to discern, and it is likely that some varieties were being produced and used at the same time (Leins 2012). Of most significance for this research, this coinage is particularly marked in the substantial proportion of issues that include human head and horse imagery when compared to other coin issuers (Table 1).

\begin{tabular}{|l|l|l|l|}
\hline Issuer & $\begin{array}{l}\text { \% of VA } \\
\text { types } \\
\text { with } \\
\text { horse }\end{array}$ & $\begin{array}{l}\text { \% of VA } \\
\text { types } \\
\text { with head }\end{array}$ & $\begin{array}{l}\text { Total } \\
\text { number } \\
\text { of VA } \\
\text { types }\end{array}$ \\
\hline Southern & $54 \%$ & $29 \%$ & 168 \\
\hline Kent & $73 \%$ & $6 \%$ & 73 \\
\hline $\begin{array}{l}\text { North- } \\
\text { eastern }\end{array}$ & $99 \%$ & $17 \%$ & 124 \\
\hline Western & $97 \%$ & $37 \%$ & 38 \\
\hline $\begin{array}{l}\text { South- } \\
\text { western }\end{array}$ & $25 \%$ & $21 \%$ & 75 \\
\hline $\begin{array}{l}\text { East } \\
\text { Anglian }\end{array}$ & $90 \%$ & $16 \%$ & 71 \\
\hline $\begin{array}{l}\text { North } \\
\text { Thames }\end{array}$ & $60 \%$ & $30 \%$ & 260 \\
\hline
\end{tabular}

Table 1: Percentage of VA coin types per issue region (after Hobbs), with horse and human head imagery (Iron Age coin typologies follow Van Arsdell's classification (forthwith referred to as VA-type), as presented by the Cetlic Coin Index (CCI, from where much of the data derives). The individual CCI coin reference number or PAS number will also be used in relation to specific coins. Issue regions follow Hobbs (1996))

The horses on Western coins are always depicted as moving, never static. They are either shown running or leaping, with tails (sometimes three) out behind them, almost at ninety degrees to the body. The proportions of types with human heads on stylised, abstract or head derivatives (Figure 2), is also marked in the Western issues 
(Table 1). These features contribute to the highly distinctive appearance of Western coinage from that of other issue regions. Another feature of note on Western coinage is that the image on the reverse of the coins is always a horse and therefore the horse and human head images are always on opposite faces. While some issue types are without heads on the obverse, and instead depict tree imagery, abstract designs (possibly derived from human head imagery), and written names, the image of the horse remains dominant on the reverse. The horse is thus the most dominant image and human head is the second most common image across the Western coinage.

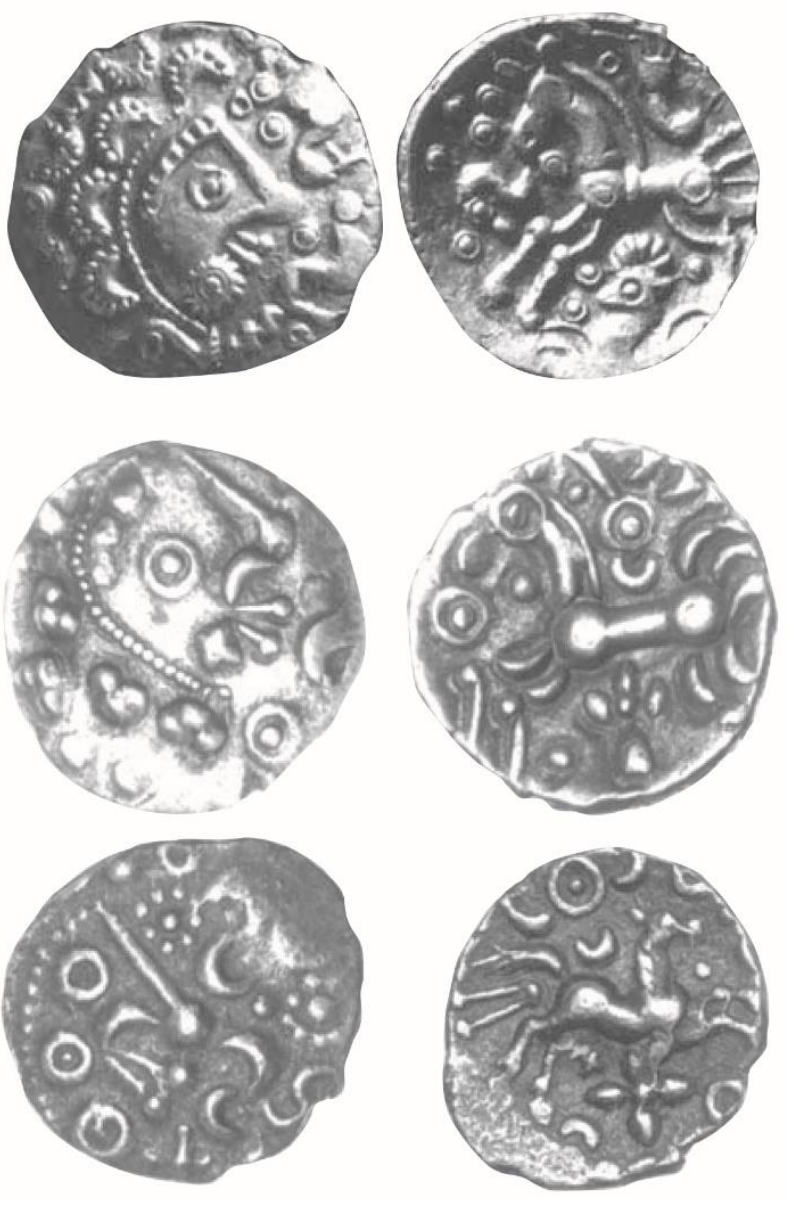

Figure 2: Dobunnic coins showing typical moving horse with three tails on reverse and stylised (top VA 1020, CCI-840660), abstract (middle VA 1049, CCI- 001555) or head derivative (bottom VA 1135-1, CCI-000039) on obverse (Coin images all with permission from the Portable Antiquities Scheme under the CC by attribution licence). 
As with most British Iron Age coins, the basic premise of the horse and head is a mimic of other coins and can broadly been traced back to the coins of Philip II of Macedon with the head of Apollo on the obverse and the chariot of the sun god on the reverse (Green 1992b, 157; Allen 1961; Williams and Creighton 2006, 54). The copying of these images does not however, suppose a similar transfer of meaning. Any Classical or Romano-Celtic association with the imagery on Iron Age coins must therefore be made with caution. Instead, Iron Age coins should be situated alongside the evidence for geographically and temporally relevant cosmologies, such as any possible animistic beliefs and practices. This is particularly important in relation to the images on coins produced in western Britain, where evidence for continental ('Roman'), material connections (and therefore likely cosmological ideas), is less obvious than in the south and east during the later Iron Age and where Iron Age beliefs were also perhaps less affected by such external influence.

The central images on the obverse and reverse of British Iron Age coins are often surrounded by a range of smaller images (Figure 3 ). These images have been referred to as fill-in ornaments (Allen 1980, 149) amalgamation switchers (Van Arsdell 2008a; 2008b), or entopic images (Williams and Creighton 2006), depending on the interpretive methodological approach taken. When combined with subtle or blatant variations in the portrayal of familiar (or copied) images such as the horse, these peripheral images could have a profound effect on the significance of the overall image. This is especially the case if we are to consider all the individual parts of the coin face as fragmentary, combining to form something complete. Common images on Western coins include wheels, crescents, pellets and flowers or stars (sometimes crosses). These will only briefly be referred to below and additional analysis of these is required to fully appreciate how subtle variations may affect the meaning of the coin. 


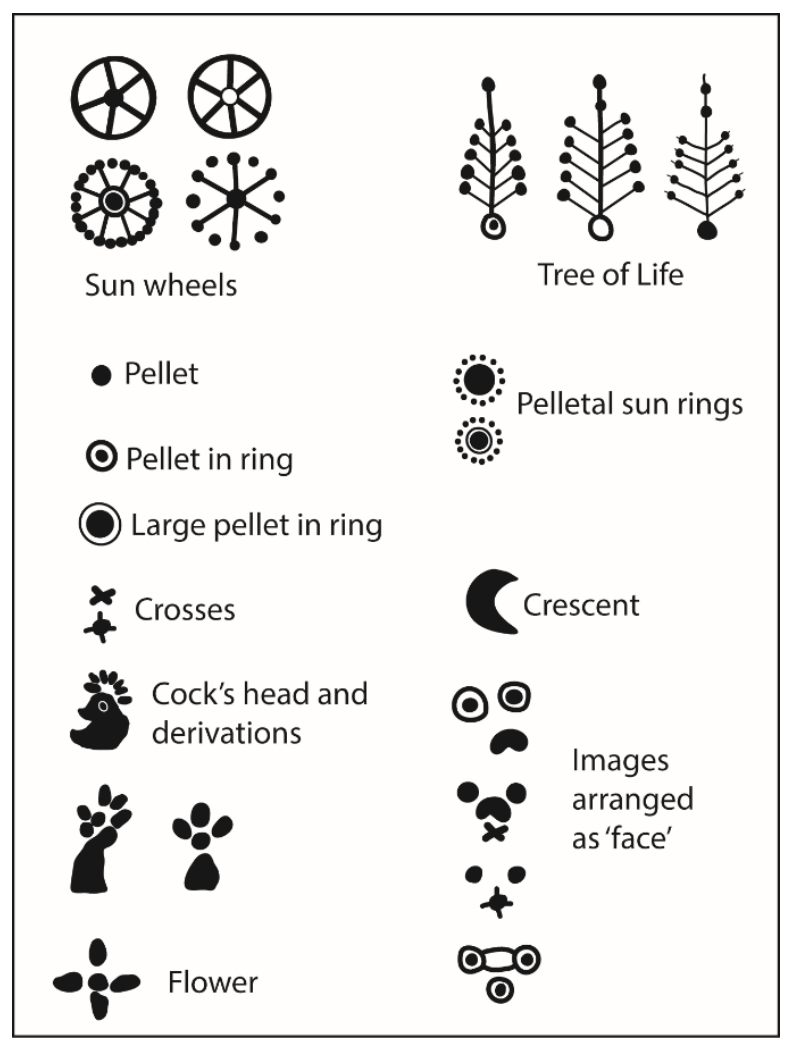

Figure 3: Glossary of some smaller images on Dobunnic coins

To date, research surrounding the imagery on British Iron Age coins has largely related to classification and categorisation; creating typologies and chronologies based upon issuers, issue regions, and stylistic development (Allen 1944; 1960; 1980; Hobbs 1996; Mack 1953). This was expanded by concentrating on identification of the images to better understand the development and distribution of coinage and what this may be able to tell us about Iron Age life (Allen 1958; 1961). In turn, this led to discussions of Iron Age tribal power, politics, and Iron Age economics (Allen 1970; 1976; Haselgrove 1987; 1993; de Jersey 2001; Rodwell 1976; Van Arsdell 1989; 1992; 1994). The implicit link between Iron Age coins and tribal power and identity has had a considerable impact upon the study of Iron Age coinage and on our understanding of Iron Age societies as a whole. Such an understanding is now becoming increasingly challenged (Leins 2012; Moore 2011), and considering this, the function and meaning 
of Iron Age coins also warrants further contemplation. Functionalist approaches (e.g. Collis 1974), have been criticised (Haselgrove 1993; de Jersey 2001; 2006; Van Arsdell 1989), with a strong argument to suggest that British Iron Age coins did not function as money (Haselgrove 1993; Wellington 2006). Instead, the coinage is generally considered as high value metalwork which is linked to notions of status and power within the changing nature of later Iron Age social structures (Creighton 2000; Haselgrove and Wigg-Wolf 2005; Pudney 2011; Sharples 2010; Wellington 2006).

The semiotics of coins from the British Iron Age has also been touched upon. Early attempts at interpreting the imagery were largely reliant upon the opinions of Roman outsiders (i.e. classical sources from Caesar, Tacitus and Strabo), or were centred upon Celtic mythology (Davies 1809,595; Evans 1864; Ruding 1840, 269), both of which draw on sources outside the chronological and/or geographic milieu of the coins themselves. More recently, broader imagery on coinage has been addressed, drawing association with shamanic practice, specifically three-stage trance processes (Creighton 1995; 2000; Williams and Creighton 2006), where the imagery may be metaphors indicative of various trance states. Such approaches begin to set Iron Age coins within the world views of the societies creating and using them, linking them to evidence for religious performance and cult practice. The images of some Iron Age coins have therefore been argued to derive from the repertoire of seers, who were likely involved in a Druidic or similar religious order (Creighton 1995, 297). Coins are either created during or in association with such ritual performances and the imagery therefore correlates to the language of power at the time, that is of the shaman, seer, or religious elite.

The fruitfulness and dangers of attempting to understand the meanings of the specific images on Iron Age coins has also been explored (Van Arsdell 2007a; 2007b; 
2008a; 2008b; 2008c; 2009a; 2009b; 2010a; 2010b; 2015a; 2015b; 2015c). Using

Umberto Eco's (1978) work on semiotics, Van Arsdell presents a clear argument for the ways in which the images on coins can be analysed. This approach attempts to understand the symbols as code, which can be deconstructed into sememes, thus breaking down the meaning of an image and groups of images into denotations. Interpretations also attempt to set the coins within their contiguous context, considering the possible audience of the imagery and what the images may mean for each. Most importantly, this method generates much opportunity for discussion and analysis of a rather un-developed subject. The main issue with Van Arsdell's particular method however, is that it denotes all images on Iron Age coins as symbols and thus fails to engage with the implications of more recent semiotic and other material culture theories and methodologies. Images are also often interpreted in a Classical context, drawing upon associations with Romano-Celtic or Romano-British iconography (Van Arsdell 2009b). This results in the images being considered somewhat out of their temporal and geographic context. The relationship between the sign (image and/or object) and the referent (meaning) may therefore be oversimplified or misconstrued.

\section{A sociosemiotic approach to Iron Age coins}

A more convincing approach to material culture exists, which incorporates the materialist and mentalist approaches with semiotics and includes concepts of embodied meaning and metaphor. This approach can be termed sociosemiotics (Knappett 2005, 85). In this approach minds, agents, and objects are no longer viewed as constrained entities but are considered as mutual and spilling across fluid boundaries. The objectas-sign and object-as-material need considering rather than viewing the sign properties of the object as being different and separate to its materiality (Knappett 2005,86). Thus, an image or object can be broken down into networks of icon, index, and symbol, which 
link to the referent in different ways. The sign can be linked to the referent through similarity (the sign is therefore an icon). For example, a wedding ring can be viewed as an icon because its eternal circle epitomises the union that it has come to represent. Icons usually demand a basic level of knowledge for them to be understood. An index is a sign that is linked to the referent through causality or contiguity (such as a footprint or clock). The third type of relationship between sign and referent is a symbolic one, and is where both are mediated by an agreed upon link irrespective of any physical characteristics. The best example of this is language, where specific combinations of sounds and written scripts are commonly understood yet may have no aural or visual connection to what they are understood to represent (Knappett 2005, 89-90).

No object is intrinsically iconic, indexical or symbolic but instead is inferred as such. An object may be understood variably as an icon, index or symbol in different situations depending on the perspective and intentionality of related social agents. It is also necessary to consider the abductive or performative character of indices (after Eco 1978). For example, abductive indices (icon, index or symbol), require prior knowledge to be understood. Performative indices relate to signs where the meaning is created spontaneously, at the moment it is manifested. A photograph, as an icon and an index is also both abductive and performative (Knappett 2005, 97). It is iconic in that it bears a perceived likeness to what it represents. It is abductive in that it requires a level of knowledge to recognise the images within it. It is an index, in that it comes into being under specific circumstances and was therefore physically forced to correspond. Similarly, it is performative, in that the meaning becomes apparent at the moment it is created. Thus sign, icon and index, objects, actions, and ideas are diversely associated by similarity (as Van Arsdell acknowledges), but also by contiguity, factorality, causality, and convention (Knappett 2011, 106). If we are to consider Iron Age coins as 
being used as commercial objects then it would be an abductive symbol with an agreed value. If, however, we continue to understand these objects as highly-valued and powerful pieces of metalwork then we should perhaps explore the images on Iron Age coins by considering its appearance and how its meaning first becomes apparent; as a performative index.

\section{Shifting shapes: Coins, humans, and horses}

If the coins are an index bound within wider material and cosmological networks (Knappett 2011), the regular occurrence of the human head and horse warrants additional consideration. Depending on the relationship of the imagery it may infer something regarding the relationship of the referents. On analysis, there are some marked patterns in the way the images appear on the Western coins.

Western coin types with heads on the obverse tend to be silver coins. The head designs range from being realistic (or naturalistic), to those that are recognisable human heads, (although they are stylised) and those that are highly abstract, yet still retain the essence of a human head (Figure 2). Generally, all the Western coins with human heads are either stylised or abstract, with only one type (VA 1057-1) depicting something more realistic and life-like. All Western coins depicted with stylised or abstract heads are pictured showing the right side of the face, thus from the viewer's perspective the head is turned to the right. The realistic head is pictured in the opposite direction.

The earliest Western coins depicting human heads are thought to appear from the start (c. $35 \mathrm{BC}$ ), although the chronology of the coinage is problematic and it is uncertain whether gold coins were struck continuously after c. 30 BC (Leins 2012, 5056). It is however, considered that in a relatively short amount of time gold and copperalloy Western gold and silver units were being produced, with silver being the most common for a period. These small metal discs continue to be adorned with the images 
of human heads on the obverse, while retaining the central image (in various formats), of the horse on the reverse, until the end of coin production during the 40s A.D.

Based on the interpretations of the chronological development of these coins, but being careful not to rely too heavily upon them, the depiction of heads on Western coinage tends to become more abstract through the period of issue. The much more realistic heads thus likely appear later in the chronology than the abstract, although the concurrent production of multiple types is possible. These realistic heads are also usually associated with inscribed names. Such inscribed Western coins appear c. 30 BC, the first being those inscribed with CORIO (Figure 6). The diverse details of the horse are also varied in abstraction. Images surrounding the horse additionally begin to change and become much more varied and complex. Some inscriptions are even put around the horse on the reverse, therefore creating a human head or a tree-like image on the obverse and horse, peripheral images, and inscription on the reverse. One type includes a head with a name on the obverse (VA 1057-1).
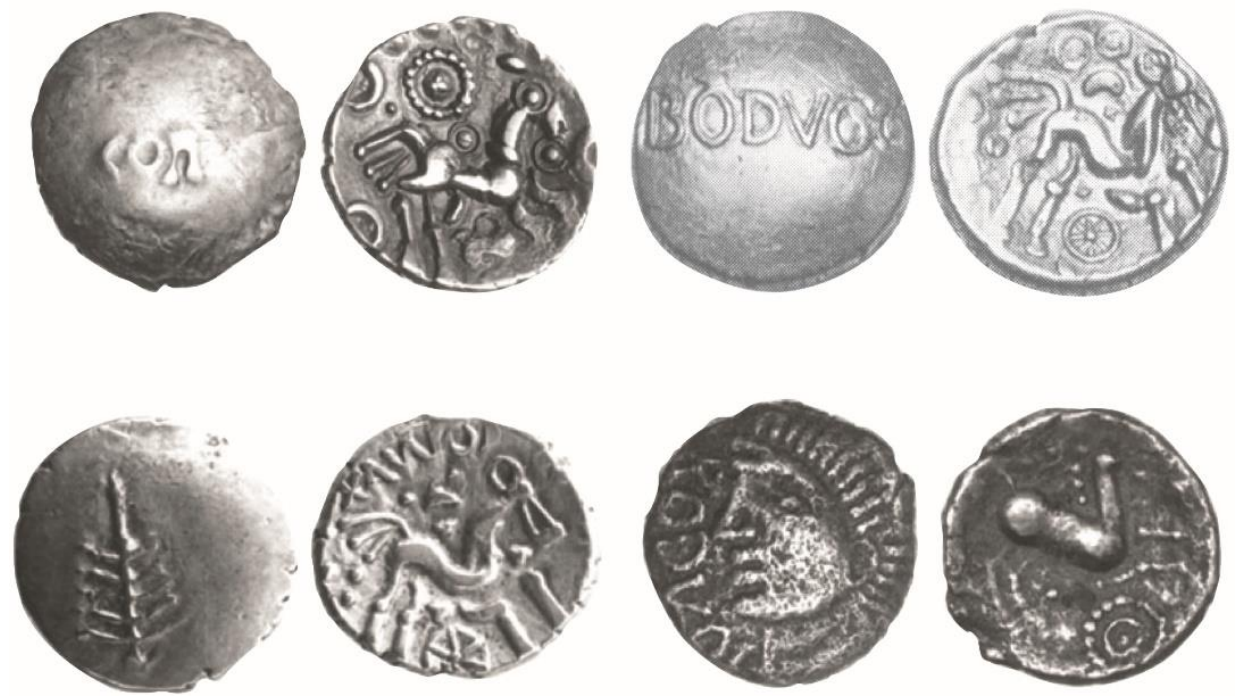

Figure 4: examples of inscribed coins. Inscription could be on the obverse or the reverse. (top L: COR(io) VA 1052, CCI-000433; top R: BODVOC, VA 1039, CCI- 
971074; bottom L: COMUX on reverse, VA 1092, CCI-660022; bottom R: BODVOC with head on obverse VA 1092, CCI-000038)

Not only on the opposite face of the coin to the head, the horse is almost always depicted on these coins in the opposite direction (Figures 2 and 6). If the head is facing to the right as the coin is viewed, the horse is facing the left, i.e. moving from right to left across the coin. Thus, the horse and human could be viewed as facing each other, coming together or alternatively, could be viewed as two faces of the same thing or being. Or further still, as opposites. The coins that have highly abstract heads, of which there are seven types recorded by Van Arsdell, also follow the same pattern. It is perhaps significant to note that the heads depicted are always male. This association of men and horsemanship has been noted within other European, Iron Age societies (Frie 2017), and while is not the core focus of this paper, perhaps indicates some social distinction in human-horse relationships.

There is much more variety in the physical appearance of the horse, as with the human head. This range in abstracted designs (horse and head), would fit within stage three from Williams and Creighton's study of trance imagery $(2006,56)$, where weightless designs link to out of body experiences and impressions of the spirit-body becoming dissociated from the real body. The exceptions to this opposite positioning are the coins with 'head derivatives' (e.g. VA 1135-1 and 1137-1). In these types, the horse is depicted in the same direction as the head (see figure 2). This could relate to the status of the human within the dissociative process, at a stage where they are less obviously a human. Thus, the human and horse are more closely linked and less divisible.

As performative indices, the changes in the coin imagery may indicate shifts in the ways in which horses, humans and objects cohabited, all of which could be 
inextricably linked to the trance stages as outlined by Williams and Creighton (2006). Aldhouse-Green (2001) suggests that the depiction of part human and part animal 'monsters', reflect the animistic and shamanic nature of Iron Age societies. Within most animistic societies, animals are considered potential persons by virtue of their shared inner essence. This essence provides them with similar rational capacities as humans. The concept that other species have spirits and are sentient or have mental consciousness creates a hugely dynamic set of relationships between humans, animals and spirits. To help us understand the various ways in which such concepts might work in practice we can turn to ethnographic parallels. For example, in Yugakhir society everyone can transform into the body of another person (Willerslev 2007). Such transmogrification or shape-shifting involves the bodily transformation of beings. Within this there can remain clarity as to which body belongs to any given person although it is possible for someone to take on the body of a being from another species (Willserslev 2007, 89). While we cannot draw direct parallels from Yugakhir society it does help illustrate how different, non-modern, western concepts could have existed within Iron Age Britain and in doing so, opens an alternative, interpretive perspective on the evidence.

For Yugakhirs, such a transformation is never total because of the necessity to retain some self-awareness or a degree of reflexivity. The process of bodily transformation involves changes in the person that entails an altogether alien perspective. This perspective comprises a radically unfamiliar linguistic, moral, and social code (Willerslev 2007, 89) and is perhaps what is indicated in the highly abstract heads depicted on Dobunnic coins. Maintaining a sense of human identity is vital so as not to lose oneself in the alien body and therefore become neither truly one person nor the other and risk being cast out by both species. Thus, the transformation does not 
merely result in a copy of the host species nor does the human become an animal (only shamans in Yukagir society are able to transcend the animal-human interface and become the animal). Instead the human takes on the bodily form of the host species while retaining some of their former physical qualities (Willerslev 2007, 95). In doing so, they can retain their own human perspective, but also that of the host species. The person is therefore not imitating a horse but is not not a horse (after Willerslev 2007, 100). This results in fusion or synthesis somewhere in between both species.

In the context of Western coinage, the inclusion of the realistic human head or a name such as Corio, may ensure the retention of notionality, where the human perspective is preserved. The written language on coins constitutes the earliest evidence that survives for writing in the Latin script in Britain. If the writing of names upon coins is viewed within this transformative context the introduction of this type of expression and communication could indicate an increased need for a particular human identity. Questions surrounding the nature of Corio as a person (human or other) are thus raised, especially concerning their social standing.

The degree to which each of the images or writing is portrayed or stylised could therefore indicate a different stage or the transformative process or perhaps, could signify the varying perspectival notions. If the horse is to be viewed as facing the human, it could signify the initial coming together of the two species. If the coin imagery is meant to be viewed as two sides of the same being, as something part horse and part human, then the coin could be viewed as the materialisation of the therianthrope, a more advanced stage of the transformation. It is also possible that the coin is deliberately ambiguous, where the juxtaposition of the horse and human creates a third space. The image is perhaps never stable but instead reflects a state of perpetual emergence. Whichever we decide to argue, the horse and human are always intertwined 
on the coin. The coin therefore reflects a mimetic agent i.e. it is forced to mimic the therianthrope or given stage of the shapeshifting process to which the viewer can respond and interpret. While the specifics of any Iron Age shamanic or animistic transformation process are unfortunately beyond the potential reach of the evidence, interpretations presented here can be argued to indicate multiple layers of mutuality between the two species. The coin therefore, manifests a deeper relationship between humans and horses and further enhances Creighton's (2000, 22-26), argument for late Iron Age sacral kingship, where ritual performances consolidated the unions of horses and rulers, and validated an individual's sacred authority.

\section{Two become one}

To this hypothesis we can draw on wider archaeological evidence for the nature of human-horse relationships, although such evidence is often problematic. The primary function of horses in Iron Age daily life appears to have been for work (MooreColyer 1994). Horses appear to have been used to pull carts and chariots, and for riding (Bendrey 2007; Russell 2012). The horse as a pet does not emerge until their economic use is no longer a priority e.g. once motor transport is introduced (Digard 1990). For any level of horse husbandry and training to take place, a comfortable and safe environment needs to be created and maintained, especially if breeding was to take place successfully (Levine 1999). Presumably also, the training of horses for riding would differ from their training to pull wheeled vehicles, especially if pairs of horses are being used. The creation of stock pens throughout prehistoric Britain along with the rise of animal husbandry would likely therefore have included horses.

The context of later Iron Age horse husbandry however, remains somewhat uncertain. The degree to which horses were kept near or in settlements or allowed to roam as a herd is often difficult to establish. Analysis of strontium isotopes in horse 
teeth has demonstrated the movement of horses across some distances during the Iron Age. For example, strontium isotope evidence for horses possibly raised in south-west England, Wales, or even Scotland have been found in Iron Age contexts in Hampshire, although whether this is due to trade, free-roaming, or a combination of the two is uncertain (Bendrey et al. 2009). Previously, a lack of evidence for breeding at settlement sites compared to that of sheep and cattle was argued as evidence for a lack of horse breeding during the Iron Age. Instead it was suggested that horses were generally left unattended and rounded up periodically for taming and training (Wainright 1979). It has been argued that the high proportions of adult horses within faunal assemblages from some sites suggests that breeding did not take place at all settlements (Bendrey at al. 2009), but an absence of immature horses in faunal assemblages does not necessarily equate to an absence of horse breeding (Maltby 1981). Many Iron Age sites do demonstrate the presence of neonate and immature horses, indicating that certain sites may have specialised in horse-breeding (Hamilton 2000a), such as at Battlesbury Bowl, Wiltshire.

It is likely that horse husbandry practices were complex and highly variable across Iron Age Britain. Hamilton (2000b, 72), suggests that at Bury Hill, Hampshire, the number, age and sex profiles of horse remains could represent the management of 'feral' horse populations, where on rounding up, some were used in human domestic life, some mares were released for breeding, and some surplus stallions for meat consumption. The general lack of butchery marks on most Iron Age horse bones compared to cattle and sheep supposes that although potentially eaten at some sites, they were not predominately being exploited for meat (Hambleton 2008). There may indeed have existed a taboo concerning the consumption of horse meat (Green 1992a, 
37), although the archaeological evidence does not support the argument that such a taboo was widespread.

At the later Iron Age polyfocal complex Bagendon, Gloucestershire and the satellite enclosures at Salmonsbury, the dykes have been suggested to assist in the corralling and control of animals including horses (Fitzpatrick 2007). This would support the idea that in this area, the horses were perhaps left to roam and were communally rounded up at specific times. Once corralled, the animals could be tamed and trained. Training horses tends to take place on an intimate basis, where trust can emerge between human and horse with greater success (McGreevy et al. 2009). Studies have shown how specific horse-horse interactions have a corresponding horse-human interaction that can help in the training of the animals (McGreevy et al. 2009). This is presumably the same regardless of whether feral horses were rounded up or whether they were bred at settlement sites, especially if the horse requires training to work as a team and in conjunction with a chariot. For a horse to be tamed and trained a degree of empathy for the horse is required. This empathy could be reached through bodily transformation, i.e. where the human is as a horse. The human thus seduces the horse by establishing relations of empathy, transforming its perception of reality into manipulated fiction (Willaslev 2007, 104). The experience of transmogrification would permit the taming and training of horses through the ability to put oneself imaginatively in the place of another, thus replicating in one's own imagination in the perception of the other.

In this shape-shifting performance a combination of dividuals (Fowler 2005) come together to compose a person and there would exist a complex dialectic between the human and the horse. The new, emergent person is a composite of essences that can be continually circulated, monitored and transformed (Fowler 2005, 25). Diversity in 
the new human-horse person is assured since each dividual is a product of social interaction between themselves and others, and is a manifestation of the overall relationship (Fowler 2005, 25). These relationships can either be partible or permeable. In partible relations one part of the person is replaced with another while the number and type of each component is altered in permeable relations. In permeable relationships, there does not tend to be a removal of any parts but perhaps the change in the ratios or size (Fowler 2005, 32). This especially has significance in personhood where relationships involve transmogrification. Through bodily transformation personhood might become permeable rather than partible. In this sense, essences are circulated between persons and parts are transformed instead of replacing a divisible part.

The abstract human heads and abstract horses as displayed on the Western coinage promotes the suggestion that the boundaries between the human person and horse person are increasingly complex. On the Western coins, the body of the horse is presented as dis-jointed or disarticulated although all components remain in the correct anatomical position. This depiction could relate to more than simply the skill of the craftsman, especially since all the coins present the horse in various permeations of disarticulation. Through the corralling of animals and subsequent taming and training the relationship transforms into a permeable one. The human has earned the position in which they are able to negotiate bodily and perhaps spiritual boundaries, a dynamic supported by the argument that horses initiated domestication rather than humans (Levine 1999). The animal and human thus enter different rhythms of entrainment and attunement, synchronicity, and seasonality, contiguous to daily routines and performances (Brittain and Overton 2013). The transmogrification therefore becomes 
central in the negotiation of the relationship between the two beings and the wider environment.

The manifestation of this upon metalwork coins indicates the stages of this transformation but the imagery on the coins additionally incorporates the material world, specifically chariots and other celestial or animate objects. If such bodily transformation is significant within Iron Age society we should be able to find evidence of this and the associative dividuals amongst other horse-related material culture.

\section{A third wheel? Fragmentation, enchainment and totemic things}

Treatment of the horse after death and the deposition of horse-related materials can assist us in understanding the daily and the more specialised human-animal-object relationships. Structured deposits in which horse remains are included are relatively common throughout Iron Age Britain, as are those that include other species. However, there is generally less Iron Age faunal material recovered from western areas of Britain than from central southern and south-eastern areas, making this a difficult area of study. This is because of poorer preservation conditions due to generally higher levels of acidity in the soils as well as an historic concentration of archaeological research on Wessex and the south east (Hambleton 1998, 163). While the number of sites discovered and excavated across western Britain has increased since Hambleton's (1998) doctoral research was undertaken, to this author's knowledge, no detailed study exists of horse remains from western England and Wales. This makes finding an appropriately significant dataset challenging for the area in which Dobunnic coins are found and has impacted the faunal assemblages included in this paper; which lie towards the outer extents of the coin distribution. 
One example from the Upper Thames Valley is at the hillfort of Blewburton Hill. Here, four fully articulated horse skeletons were found discovered around the entranceway to the hillfort. The lack of interference from scavenging animals has been argued to suggest careful interment rather than casual burial (Harding 1872). Their association with the entranceway not only reflects the animals' importance but also perhaps their association with foundation or completion ceremonies, or some other rite of passage event (Morre-Coyler 1994, 11).

Unlike the horses at Blewburton Hill, the majority of structured or intentional deposits of horse remains often display signs that the objects deposited were deliberately broken or fragmented. One site where this occurs is Ham Hill, Somerset. Within the region of western Britain and on the edge of the Western/South-Western coin issue zones, the hillfort at Ham Hill has produced evidence for the distinct structured deposition of horse remains, horse-gear, and other animal remains and related objects (Brittain et al. 2013; Lievers et al. 2007; Slater et al. 2012). Records exist of an Iron Age chariot burial (Hoare 1827, 39), and in 2002 excavations revealed a series of pits that demonstrated regular occurrence of animal bones and metalwork (Lievers et al. 2007). Pit 136 contained seven horse skulls within one single fill. The absence of post-cranial elements was suggested to reflect deliberate and probable ceremonial selection (Lievers et al. 2007, 43). A further five pits also contained horse skulls representing a minimum of thirteen individual horses. Many of the skulls seemed to have had the lower jaw deliberately removed as indicated by the presence of teeth but absence of mandibles. The selective treatment of horses was particularly notable in relation to a lack of obvious selection for the other animal bone deposited (Lievers et al. 2007, 53). For those at Ham Hill, the horse skull appears to have been a particularly important component of the animal. The simple justification for selection of skulls is 
that they do not carry any meat and therefore would be the most economically beneficial (Moore-Colyer 1994, 12), although multifaceted motivations should not be dismissed.

Complex treatment of the horse skull after the death of the animal but prior to the deposition of its remains has also been identified in some areas. Archaeological evidence from Battlesbury Bowl, Wiltshire demonstrates the careful and selective deposition of some horse and cattle skulls (Hambleton 2013). The taphonomic wear on many of the skulls indicated that they had been cleaned some time prior to deposition, perhaps suggesting that they had been hung on walls or posts for a duration (Hambleton 2013, 490). The Battlesbury horse skulls also demonstrate an emphasis on male animals (Hambleton 2013, 490). Horses are not the only animals to undergo special treatment across Iron Age Britain (Hambleton 2013; Madgwick 2010), and it should be noted that such specialised treatment of animal remains is not limited to those animals depicted on late, pre-Roman Iron Age coinage. However, cross cultural practices involving the display of horse heads and skins has been noted by Wilson (1999), and could go some way to explaining possible post-mortem treatment of faunal remains. For example, in former Soviet Asia, heads, hoofs, and hides of horses were used to mark sacred places (Budiansky 2009, 62-4).

No explanation has yet been put forwards for how this practice may relate to more specific Iron Age beliefs or cosmologies other than a general Celtic belief that the head was the repository for the soul. A similar practice may well have taken place at Ham Hill, where skulls were curated for a time, used to mark specific spaces or used in ritual performances, finally being deposited. The age of the individual horses was generally low at Ham Hill, with a peak of animals aged to 3-5 years, redolent of the training of feral horses (Hamilton 2000a, 62). A large proportion of the horses from 
Ham Hill could have been feral, then trained, used and then killed; their remains being treated as just discussed. The excavators suggest that the predominance of prime animals may be indicative of their use in warfare (Lievers et al. 2007, 53). These particular horses may have been chosen for special treatment because of the martial roles they played. Thus, a permeable relationship formed during the training and then developed through subsequent interaction with the living horse appears to become increasingly fragmented after death. This could be significant in relation to the fragmented body parts we see on the Western coinage as well as the often-prominent heads and eyes.

This fragmentation extends beyond the human and horse. Wheeled vehicles are also often represented on the coins. Horse-related metalwork such as harness fittings, bridle bits, terrets and linch pins therefore also require consideration, especially since these items mediate the human-horse relationship once the horse is trained and especially when put to work pulling a chariot. Harness equipment is fundamental to the nature of the sensory field which connects horse and rider (Brittain and Overton 2013; Patton 2003). In turn, this plays a significant role in the bodily signage of a relationship. Harnesses and vehicle fittings were both functional and, in some cases, were designed for display in battle (Lewis 2015; Green1992a, 71). They were often highly decorative, with evidence for richly ornamented horse-gear dating from the early Iron Age until the first century AD (Green 1992a, 71). This is particularly evident in those that were buried in the Polden Hill hoard, Somerset (Brailsford 1975), and in those documented on the Portable Antiquites Scheme database (see figure 5). 


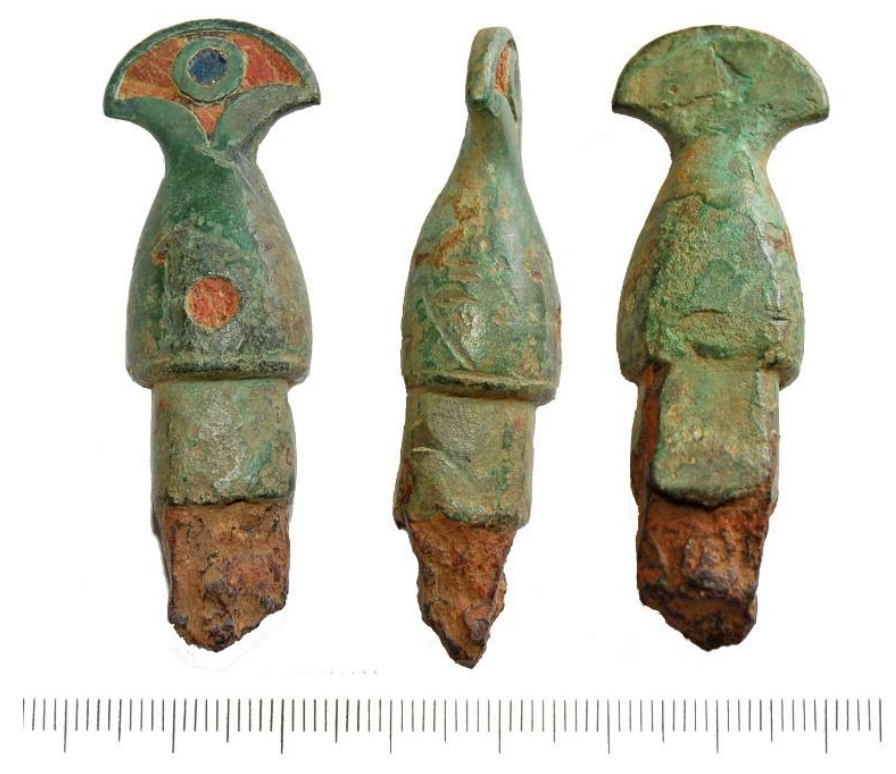

Figure 5: Iron Age linch pin terminal from Gloucestershire with decorative and enamelled terminal. PAS ID: GLO-DB46F7 (www. finds.org.uk)

The secure attribution of horse-gear to the Iron Age is difficult without contextual information (Farley 2012, 310; Garrow et al. 2009). Nonetheless Portable Antiquities Scheme (PAS) data for Iron Age/Romano-British horse-gear demonstrates clear distribution bias around the areas where Western coinage was dominant, the South-Western (Durotrigian), the East-Anglian coin region (Norfolk / Iceni) and then the North-Eastern (Nottinghamshire, Leicestershire, Lincolnshire and Northamptonshire / Corieltavi) coin issuing regions (Figure 6). These are the areas where horse-imagery on coins is more dominant compared to other imagery (see table 1). Areas of more intense metal detecting inevitably skews PAS data distributions (Robbins 2013), but a general absence across southern England could reflect a genuine absence rather than an absence of metal detecting. For example, research has demonstrated that Hampshire is one of the most densely covered counties in England (Robbins 2012, 163) yet has not produced comparable levels of horse-gear. 


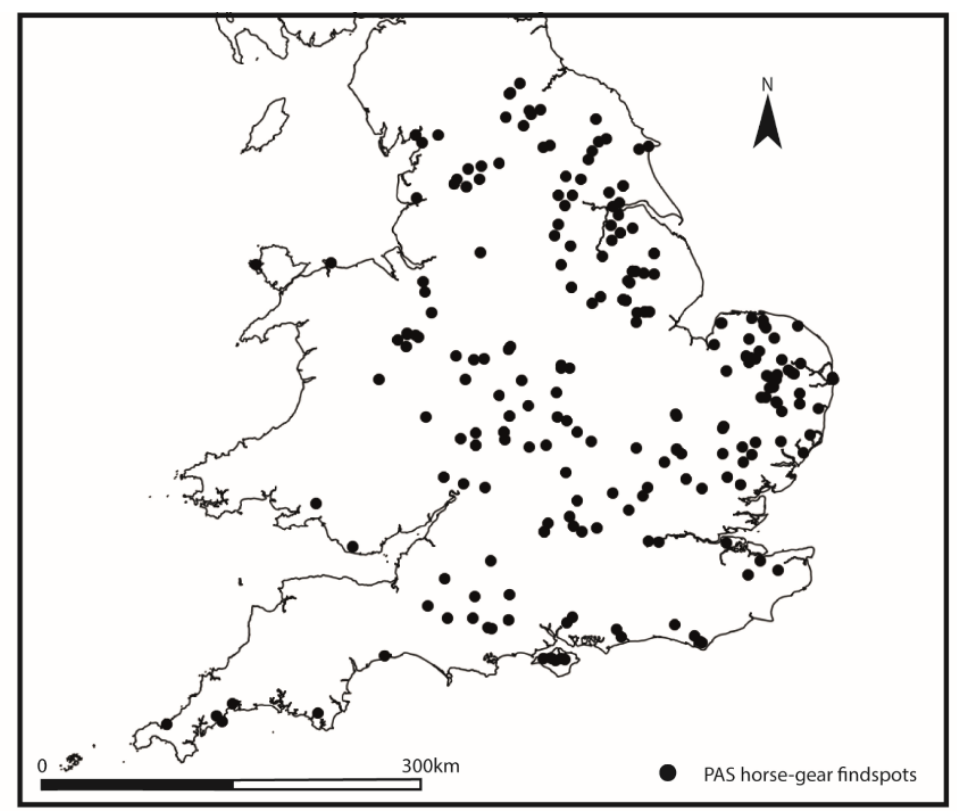

Figure 6: Distribution of findspots of horse-gear recorded on PAS database

The production and occurrence of horse and chariot fittings also appear to signify characteristic regional practices and styles in the west and north-east of Britain (Farley 2012; Gwilt 2007; Lewis 2015). If we view the argument that the creation of metalwork as something magical and mysterious (Aldhouse-Green 2002; Budd and Taylor 1995; Giles 2007; Hingley 1990; 1997; 2006) the production of both coins and highly decorative horse-related fittings becomes noteworthy and the objects themselves as potentially animate.

Giles (2008), has considered the impact of colour, abstract design, and luminosity in the creation of martial objects, including horse-gear. Such a 'technology of enchantment' (Gell 1992) is argued as bewitching people and spirits (Giles 2008,74). The need to include this on horse-gear however, does not necessarily serve to intimidate in a martial context as suggested by Giles. Instead, it could be totemic of the power, virility, and enigmatic nature of the human-horse-object enchainment. The addition of a wheeled vehicle (such as a chariot), to the human-horse-object relationship would 
require a completely new negotiation of the human-horse connection resulting in the amalgamation of human, animal, and chariot/harness/fittings, enchained as one significant being. This fragmentation and enchainment is thus part of the negotiation of human-animal-object relationships (Chapman 2013; Pudney forthcoming).

Particular motifs on metal work, especially chariot fittings, further emphasise this process. For example, increasing numbers of triskele motifs are being recorded on the PAS. The triskele, three interlocked spirals, or three bent/curved lines extending from the centre of the image, like legs or arms reaching into/out from one central point are often found on pendants, mounts and fobs dating to the Iron Age. These are rather poorly understood artefact types, and could have adorned harness decoration, items of equipment (such as chariots), or personal apparel (Jope 2000, 285). For example, the bronze triskele pendent from Abergavenny, Monmouthshire (Spratling 1968-9), four further examples from Kingsholm, Gloucestershire (Jope 2000, 285, No 225a-d), and that seen in figure 7. Those from Abergavenny and Kingsholm were without the peltae but are none the less broadly parallel examples to that from Bampton.
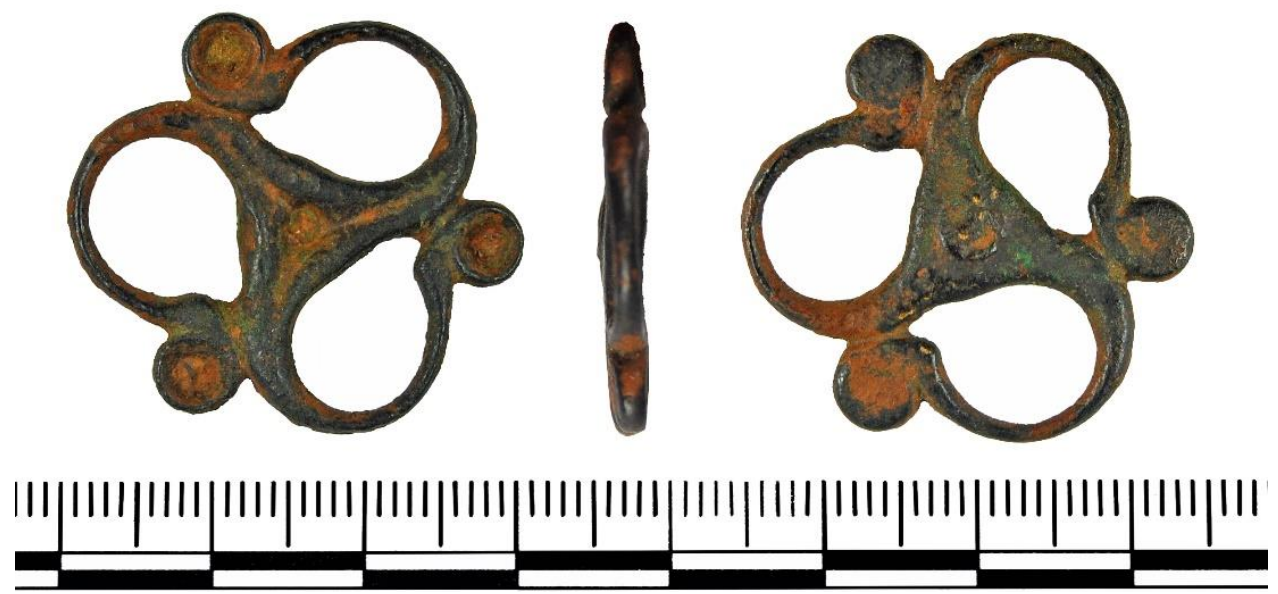

Figure 7: Triskele fob from Bampton, west Oxfordshire. (PAS ID GLO-00B794) (www.finds.org.uk) 
The Abergavenny pendant was considered to have adorned a wheeled vehicle such as a chariot (Spratling 1968-9) and therefore relates to the third agent in the rhythmic dynamic. It cannot be insignificant that amongst the PAS records categorised as Iron Age horse-gear, only chariot fittings and harness fittings are recorded with triskele decorations. There are in addition, numerous triskele objects which remain unassigned as horse-gear, but which could feasibly be so. While it is not always possible to establish the difference between bridle bits used with wheeled vehicles or whether they were used for horse riding, the author could not discern any bridle bits with triskele design within the PAS database. This further strengthens the argument for an exclusive association (perhaps totemic) between the triskele design and the horsehuman-chariot relationship rather than horse-rider relationship.

Use-wear analysis has identified that many apparently complete Iron Age chariot sets have been selected for special deposition are not in fact complete sets. Instead they are composite objects, some parts of which are much older than others meaning that each object had its own history or story (Chittock 2016). Such a phenomenon appears to be relatively common in many items selected for special deposition (Chittock 2016). Fragmented from their original context, these multiple objects are curated, modified and amalgamated to create 'new' objects, perhaps with the specific intention of deposition together. While it was not possible to conduct such analysis of the horse related metalwork from western Britain for this paper, it would be interesting to investigate whether there was evidence for such a mnemonic tradition to include stories or myths of horse-human-object(chariot) relationships.

Many structured deposits involving horse remains and trappings also consist of other objects, animals or sometimes, humans. Pits at Ham Hill including horse skulls, legs, bridle and a wheel rim were revealed during excavations in 2011. For example, pit 
1593 contained an ironwork hoard that included bridle fittings and a linch pin, as well as a finely worked antler knife handle (Slater et al. 2012). In the same year horse remains were also found deposited within a series of grain storage pits. Pit 1528 contained a horse skull within the middle fill; Pit 1607 contained a human tooth and skull fragment, foetal, burned sheep, worked bone, an animal skull and two horse bone fragments. This adds to the discovery of a grain pit sealed with a horse skull and quern stone in 2002 (pit 149, Lievers et al. 2007). Here we find a range of at least three objects as components of fragmented personhood in the human-horse-object relationship. In the act of depositing a combination of these fragmented materials together the human-horse-object is transformed from something partible into something more permeable. When placed together with a quern stone and other objects within a grain pit, this strong and virile enchainment may point to fecund propitiatory rights, not unlike those suggested at places like Danebury (Cunliffe 1992).

The inclusion of horse-related items in propitiatory contexts has an impact on how we might interpret the deposition of the coins themselves. The interment of the coins could also be seen as a similar propitiatory act where the human, horse, and object are essential to the specific desired outcome. The coin could be understood as the materialisation or totem of many of the characteristics present in the human-horseobject relationship. Unlike the deposits that contain items associated with fertility and grain production, the coin also embodies more, such as the sun, moon, and stars; all of which are also usually represented in the imagery (Pudney forthcoming).

There is a clear connection between coins and the sacred during the later Iron Age and early Roman period. Most Western issue coins have been recovered from settlement or activity sites, especially Roman temple sites (Moore 2006). For example, Bath, Henley Wood (Watts and Leach 1996), Sapperton (Moore 2001), Nettleton 
(Wedlake 1982), Uley (Woodward and Leach 1993), and Wycomb (Timby 1998), have all produced significant quantities of Western coins, enforcing the interpretation that these objects are intentionally deposited at religious or spiritual locations. This is further supported by widely acknowledged depositional tradition at sacred sites across the 'Celtic' world (Briggs et al. 1992; Curteis 2006; Haselgrove 1989; 2005; Haselgrove and Wigg-Wolf 2005). These sites could represent pre-Roman sacred locations but more importantly demonstrate a practice of coin deposition that is explicitly linked to cosmological beliefs.

Like humans and animals, Western issue coins are born, they live, and they die. Based on Roman literary sources and archaeological evidence for 'Celtic' cult and belief, it has been argued that late Iron Age societies in Britain may have thought that the soul does not perish upon death but instead passes from one body to another (Aldhouse-Green 2010). In some contexts, the deposition of coins could also relate to the interment of the spirit of the horse-human-object person into the ground. One example where this might be the case is the Farmborough hoard from North Somerset, in the southern-most limits of the Western coin zone. The hoard contained 61 Western issue gold staters, 59 of which have been identified Corio issues (Van Arsdell 1994). No other issuer or metals have been identified within this hoard, making it the only Western issue hoard to date containing a sole named issuer. The inscription of the Corio name (or derivatives of it) appears to demonstrate the emergence of a local leader, with the distribution of the inscribed coins reflecting spheres of influence (Leins 2012, 157). The role of the Corio coins within special events therefore relates to a specific person, which has a significant impact on how we might envisage the variety of contexts in which it was produced, was used, and deposited but most importantly, how the coins were understood in relation to broader cosmologies (Pudney forthcoming). Was Corio a 
human or does the name relate to an emergent or mythological human-horse-object person? Or perhaps a place (Corinium?). The act of placing the Farmborough hoard in the ground may indeed relate to the death (or destruction?) of Corio and associated relationships (Pudney 2011, 312), ensuring that their spirit is unable to pass into another realm upon death. Or perhaps they were placed in the ground as totemic objects to ensure strength and fertility.

The process of hoarding these objects also has implications for the role the coins played in Iron Age lives since hoarding has been argued to result in the bringing together of people (Garrow \& Gosden 2012,191). The social importance of the collection or accumulation of the group of objects must therefore be considered, not just the act of deposition itself (Joy 2016). Accumulating all coins of same issue region and nearly all attributed to the same 'ruler' or person suggests a common understanding surrounding these objects; they may now be considered as abductive icons and powerful actors in the extension and negotiation of social bonds. The horse-gear deposited in the ground, just as the coins, become totemic objects of the human-horse person.

\section{Conclusion}

It has been argued that British Iron Age Western coinage constitutes a composite semiosis that corresponds to the animistic and/or shamanic performance and cosmology in which it was created. The dominance of human heads and horses is significant and the varied appearance of each chronicles a regional, late Iron Age mediation and transformation of human-horse-material relations. Horses were central to Iron Age lives. Through the attainment of mimetic empathy, horses were bred, trained, and set to work. They facilitated movement and travel across the landscape and helped to provide powerful synchronisation in situations of war or conflict. This affiliation was grounded in the daily interaction between horses, humans, and objects. 
The development of the Western coinage can be understood therefore, in relation to changes in cosmological beliefs. As a performative index the Western coinage was produced during a special event in which an alteration of humans, horses, and animate objects occured. The coins should not therefore, be regarded as static statements of power but as performative agents within transformative events. Once produced and used as a high-value item of gift exchange to mediate social allegiances, the coin altered to an abductive icon; an image of an understood performance yet also an animate object, perhaps even totemic. Such an animate object once again became a partible element of personhood as the transformative essence was extended through the exchange of objects.

Finally, through the depositional treatment of horse remains and related metalwork by humans, the continued fragmentation, enchainment, and re-affirmation of the essences of dividuals was performed. In its creation, use, and deposition the Western issue coinage was central in the negotiation of personhood and propitiatory rights.

\section{Moving forwards}

There is potential to further explore human-animal relationships and the role of coins in Iron Age Britain. This short, speculative inquiry has only touched upon the potential significance of British Iron Age Western coinage and has presented preliminary analysis of only the core imagery. There is therefore scope to consider what the implications of such thinking might be upon an understanding of the plethora of other images and materials, and the implications this may have on our comprehension of Late Iron Age societies. Additionally, such an approach could be extended to other coin issue regions, such as the East-Anglian and North Eastern coinages, with a view to further investigate the existence of regional patterns of human-horse relationships. 


\section{Acknowledgements}

Thanks must go to the Portable Antiquities Scheme for providing full access to the data and for use of specific coin and artefact images under the CC BY attribution licence. Thanks also to Adam Gwilt (National Museum Wales), for all his help and advice on horse-related metalwork and for his comments on early drafts of this paper; to Ruth Nugent, Nick Overton and Barry Taylor for their enthusiastic discussions regarding Iron Age animals and cosmologies. Thanks finally to the anonymous reviewers and editor for their encouraging and constructive comments. Any mistakes remain the author's own.

\section{References}

Aldhouse-Green M J (2000) Seeing the wood for the trees: the symbolism of trees and wood in Ancient Gaul and Britain. Canolfan Uwchefrydiau Cymreig a Cheltaidd Prifysgol Cymru

Aldhouse-Green M J (2001) Cosmovision and metaphor: monsters and shamans in Gallo-British cult-expression. European Journal of Archaeology 4(2), pp203-232.

Aldhouse-Green M J (2002) Any old iron! symbolism and ironworking in Iron Age Europe. In: M J Aldhouse-Green and P V Webster (Eds) Artefacts and Archaeology: Aspects of the Celtic and Roman World. Cardiff: University of Wales Press, pp8-19.

Aldhouse-Green M J (2004) An Archaeology of Images. Iconology and cosmology in Iron Age and Roman Europe. London: Routledge

Aldhouse-Green M J (2010) Caesar's druids: story of an ancient priesthood. Yale University Press. 
Allen D F (1944) The Belgic dynasties of Britain and their coins. Archaeologia 90, pp146.

Allen D F (1958) Belgic coins as illustrations of life in the late pre-Roman Iron Age of Britain. Proceedings of the Prehistoric Society 24, pp43-63.

Allen D F (1960) The origins of coinage in Britain: a reappraisal. In: S S Frere (Ed) Problems of the Iron Age in Southern Britain. University of London Occasional Paper no. 11. University of London Institute of Archaeology, pp97-308.

Allen D F (1961) A study of Dobunnic coinage. In E M Clifford (ed) Bagendon: a Belgic oppidum. Cambridge: Heffer, pp75-149

Allen D (1970) The coins of the Iceni. Britannia 1, pp1-33.

Allen D F (1976) Wealth, coinage and money in Celtic society. In: J V S Megaw (Ed) To illustrate the monuments. Essays on archaeology presented to Stuart Piggott on the occasion of his sixty-fifth birthday. London: Thames \& Hudson. pp200-208

Allen D F (1980) The Coins of the Ancient Celts. Edinburgh: Edinburgh University Press.

Bendrey R (2007) Work-and age-related changes in an Iron Age horse skeleton from Danebury hillfort, Hampshire. Archaeofauna 16, pp73-84.

Bendrey R Hayes T E and Palmer M R (2009) Patterns of Iron Age Horse Supply: An Analysis of Strontium Isotope Ratios in Teeth. Archaeometry 51(1), pp140-50.

Brailsford J W (1975) The Polden Hill Hoard, Somerset. Proceedings of the Prehistoric Society 41, pp222-234. 
Briggs D, Haselgrove C and King C E (1992) The Iron Age and Roman coins from Hayling Island temple. British Numismatic Journal 62, pp1-62.

Brittain M and Overton N J (2013) The Significance of Others: A Prehistory of Rhythm and Interspecies Participation. Society and Animals 21, pp134-149.

Brittain M, Evans C and Sharples N (2013) Excavations at Ham Hill, Somerset. 2012. Cambridge Archaeological Unit Report No.1159.

Budd P and Taylor T (1995) The faerie smith meets the bronze industry: magic versus science in the interpretation of prehistoric metal-making. World Archaeology 27, pp 33-143.

Budiansky S (2009) The Nature of Horses. Their Evolution, Intelligence and Behaviour. London: Weidenfeld \& Nicolson

Chapman J (2013) Fragmentation in archaeology: People, places and broken objects in the prehistory of South Eastern Europe. Routledge: London.

Chittock H (2016) Pattern and Purpose in Iron Age East Yorkshire (Doctoral Thesis, University of Southampton).

Collis, J R (1974) A Functionalist Approach to pre-Roman Coinage. In: P J Caseyand R Reece, (Eds) Coins and the Archaeologist. Numismatic Fine Arts Council, pp111.

Creighton J (1995) Visions of power: imagery and symbols in Late Iron Age Britain. Britannia 26, pp285-301. 
Creighton J (2000) Coins and Power in Late Iron Age Britain. Cambridge: Cambridge University Press.

Cunliffe B (1992) Pits, preconceptions and propitiation in the British Iron Age. Oxford Journal of Archaeology, 11(1), pp69-83.

Curteis M (2006) Distribution and ritual deposition of Iron Age coins in the South Midlands. In: P de Jersey (Ed) Celtic Coinage: New Discoveries, New Discussion. Oxford: BAR International Series, pp61-79.

Davies E (1809) The Mythology and Rites of the British Druids. London: J. Booth.

Digard J-P (1990) L'Homme et les Animaux Domestiques: Anthropologie d'une Passion. Paris: Fayard.

Eco U (1978) A Theory of Semiotics. New York: John Wiley \& Sons

Evans J (1864) The Coins of the Ancient Britons. London: J. Russell Smith.

Farley J (2012) At the Edge of Empire: Iron Age and early Roman metalwork in the East Midlands. (Doctoral Thesis. University of Leicester.

Fitzpatrick A P (2007) The later Bronze Age and Iron Age. In: P J Webster (ed) The Archaeology of South West England. Taunton: Somerset Heritage Service, pp 117144.

Fowler C (2005) The Archaeology of Personhood. An anthropological approach. London: Routledge. 
Frie, A. C. (2017) Horses and the Embodiment of Elite Masculinity in the Dolenjska Hallstatt Culture. Oxford Journal of Archaeology, 37(1), pp25-44

Garrow D and Gosden C (2012) Technologies of Enchantment?: Exploring Celtic Art: 400 BC to $A D$ 100. Oxford: Oxford University Press.

Garrow D, Gosden C, Hill J D, \& Ramsey C B (2009) Dating Celtic art: a major radiocarbon dating programme of Iron Age and early Roman metalwork in Britain. Archaeological Journal, 166(1), pp79-123.

Gell A (1992) The technology of enchantment and the enchantment of technology. In: J Coote and A Shelton (Eds) Anthropology, Art and Aesthetics. Oxford: Oxford University Press, pp40-63.

Giles M (2007) Making Metal and Forging Relations: Ironworking in the British Iron Age. Oxford Journal of Archaeology 26(4), pp395-413.

Giles, M. (2008) Seeing red: the aesthetics of martial objects in the British and Irish Iron Age. In: D Garrow (Ed) Rethinking Celtic Art. Oxford: Oxbow, pp59-77.

Gosden C (2012) Magic, materials and matter: understanding different ontologies. In: J Maran and P W Stockhammer (Eds) Materiality and Social Practice. Transformative Capacities of Intercultural Encounters. Oxford: Oxbow, pp13-19.

Green M J (1992a) Animals in Celtic Life and Myth. London: Routledge.

Green M J (1992b) The iconography of Celtic coins. In: M Mays (Ed) Celtic Coinage: Britain and Beyond. The Eleventh Oxford symposium on coinage and monetary history. BAR British Series 222. Oxford: BAR, pp 151-64. 
Green M J (1996) Celtic Art. London: Everyman Art Library.

Gwilt A (2007) Silent Silures? Locating people and places in the Iron Age of south Wales. In: C Haselgrove and T Moore (Eds) The Later Iron Age in Britain and Beyond. Oxford: Oxbow, pp297-328.

Hambleton E (1998) A comparative study of faunal assemblages from British iron age sites (Doctoral thesis, Durham University).

Hambleton E (2008) Review of Middle Bronze Age-Late Iron Age Faunal Assemblages from Southern Britain. Portsmouth: English Heritage.

Hambleton E (2013) The Life of Things Long Dead: a Biography of Iron Age Animal Skulls from Battlesbury Bowl, Wilthsire. Cambridge Archaeological Journal 23(3), pp477-494.

Hamilton J (2000a) Animal Husbandry: the evidence from the animal bones. In: B Cunliffe (Ed) The Danebury Environs Programme (volume 1). Oxford: Oxford University Committee for Archaeology Monograph 48, pp59-77

Hamilton J (2000b) Animal Bones. In: B Cunliffe and C Poole (Eds) The Danebury Envrions Programme: the Prehistory of a Wessex Landscape - Vol. 2, Part 2: Bury Hill, Upper Clantford, Hants. 1990. Oxford: Oxford University Committee for Archaeology Monograph 49, pp67-73.

Haselgrove C (1987) Iron Age coinage in south-east England: the archaeological context. BAR British Series 174. Oxford: BAR. 
Haselgrove C (1989) Iron Age coin deposition at Harlow Temple, Essex. Oxford Journal of Archaeology 8, pp73-88.

Haselgrove C (1993) The Development of British Iron Age Coinage. The Numismatic Chronicle 15, pp31-63.

Haselgrove C (2005) A trio of temples: a reassessment of Iron Age coin deposition at Hayling Island, Harlow and Wanborough. In: C Haselgrove and D Wogg-Wolf (Eds) Iron Age Coinage and Ritual Practices. Mainz: Verlag Philipp von Zabern, pp22-48

Haselgrove C and Wigg-Wolf D (2005) Iron Age Coinage and Ritual Practices. Mainz: Verlag Philipp von Zabern.

Hingley R (1990) Iron Age 'Currency Bars': The Archaeological and Social Context. Archaeological Journal 147, pp1-117.

Hingley R (1997) Iron, Ironworking and Regeneration: a study of the symbolic meaning of metalworking in Iron Age Britain. In: Gwilt, A. and Haselgrove, C. (Eds) Reconstructing Iron Age Societies. Oxford: Oxbow, pp9-15.

Hingley R (2006) The Deposition of Iron Objects in Britain during the Later Prehistoric and Roman Periods: Contextual Analysis and the Significance of Iron. Britannia 37, pp213-257

Hoare R C (1827) An account of antiquities found at Hamden Hill, with fragments of British chariots. Archaeologia 21, p39. 
Hobbs R (1996) British Iron Age Coins in the British Museum. London: British Museum Press.

Ingold T (2000) The Perception of the Environment: essays on livelihood, perception and the environment. London: Routledge.

Ingold T (2007) Materials against materiality. Archaeological Dialogues, 14, pp1-16.

de Jersey P (2001) Celtic Coinage in Britain. Princes Risborough: Shire Publications Ltd

de Jersey P (2006) Celtic coinage: new discoveries, new discussion. Oxford: BAR International Series

Jope E M (2000) Early Celtic Art in the British Isles. Oxford: Oxford University Press.

Joy J (2016) Hoards as collections: re-examining the Snettisham Iron Age hoards from the perspective of collecting practice. World Archaeology, 48(2), pp239-253.

Kemmers F and Nanouschka M (2011) Rethinking numismatics. The archaeology of coins. Archaeological Dialogues 18(1), pp87-108.

King A and Soffe G (1994) The Iron Age and Roman temple on Hayling Island. In: A P Fitzpatrick and E L Morris (Eds) The Iron Age in Wessex: Recent Work. Trust for Wessex Archaeology, pp114-16.

Knappett K (2005) Thinking Through Material Culture. An Interdisciplinary Perspective. Philadelphia: University of Pennsylvania Press. 
Knappett K (2011) An Archaeology of Interaction: network perspectives on material culture and society. Oxford: Oxford University Press.

Leins I (2012) Numismatic data reconsidered: coin distributions and interpretation in studies of late Iron Age Britain. (Doctoral Thesis, Newcastle University)

Levine M (1999) Botai and the origins of horse domestication. Journal of Anthropological Archaeology 18, pp29-78.

Lewis A S G (2015) Iron Age and Roman Era Vehicle Terrets from Western and Central Britiain: An Interpretive Study. (Doctoral Thesis, University of Leicester)

Lievers M, Chisham C, Kinght S, and Stevens C (2007) Excavations at Ham Hill Quarry, Hamdon Hill, Montacute, 2002. Somerset Archaeology and Natural History 150, pp39-62

Mack R P (1953) The coinage of Ancient Britain. London: Spink

Madgwick. R. (2010) Bone modification and the conceptual relationship between humans and animals in Iron Age Wessex. In: J Morris and M Maltby (Eds.) Integrating Social and Environmental Archaeologies: Reconsidering Deposition. British Archaeological Reports International Series 2077, Oxford: Archaeopress, pp66-82.

Maltby M (1981) Iron Age, Romano-British and Anglo-Saxon animal husbandry: a review of the faunal evidence In:M Jones and G Dimbleby (Eds) The Environment of Man: The Iron Age to the Anglo-Saxon period, Oxford: BAR British Series 87, pp155-203. 
McGreevy P D, Oddieb C, Burton F L, and McLeand A N (2009) The horse-human dyad: Can we align horse training and handling activities with the equid social ethogram? The Veterinary Journal 181(1), pp12-18

Moore T (2001) Hailey Wood Camp: a Roman Temple complex in the Cotswolds? Transactions of the Bristol and Gloucestershire Archaeological Society 119, pp8393.

Moore T (2006) Iron Age Societies in the Severn Cotswolds. Developing Narratives of Social and Landscape Change. BAR British Series 421. Oxford: Archaeopress.

Moore T (2011) Detribalizing the later prehistoric past: Concepts of tribes in Iron Age and Roman studies. Archaeological Dialogues 11(3), pp334-360

Moore-Colyer R J (1994) The horse in British prehistory: some speculations. Archaeological Journal, 151(1), pp1-15.

Oswald A (1997) A doorway on the past: practical and mystic concerns in the orientation of roundhouse doorways. In: Gwilt, A. and Haselgrove, C. (Eds) Reconstructing Iron Age Societies. Oxford: Oxbow, pp87-95.

Pearson M P (1999) Food, sex and death: cosmologies in the British Iron Age with particular reference to East Yorkshire. Cambridge Archaeological Journal, 9(1), pp43-69.

Patton P (2003) Language, power, and the training of horses. In Wolfe C (Ed), Zoontologies: The question of the animal. Minneapolis, MN: University of Minnesota Press, pp83-99. 
Pudney C (2011) Environments of Change: Social identity and material culture in the Severn Estuary from the First century BC to the second century AD. (Doctoral Thesis, Cardiff University)

Pudney C (forthcoming) Coins and Cosmologies in Iron Age Western Britain.

Robbins K (2012) From past to present: understanding the impact of sampling bias on data recorded by the Portable Antiquities Scheme (Doctoral Thesis, University of Southampton).

Robbins K (2013) Balancing the Scales: Exploring the Variable Effects of Collection Bias on Data Collected by the Portable Antiquities Scheme, Landscapes, 14(1), pp 54-72.

Rodwell W J (1976) Coinage, oppida and the rise of Belgic power in South Eastern Britain. In: Cunliffe B and Rowley R (eds) Oppida: the beginnings of urbanisation in barbarian Europe. BAR Special Series 11. Oxford: British Archaeological Reports, pp184-367.

Ruding R (1840) Annals of the Coinage of Great Britain. London.

Russell N (2012) Social Zooarchaeology: Animals and Humans in Prehistory. Cambridge: Cambridge University Press

Sharples N (2010) Social relations in later prehistory: Wessex in the first millennium $B C$. Oxford: Oxford University Press.

Slater A, Brittain M, Evans C, and Sharples N (2012) Excavations at Ham Hill, Somerset, 2011. Cambridge Archaeological Unit Report No. 1101 
Spratling MG (1969) A bronze loop-shanked triskele pendant from Flannel Street. In: Probert L A, Davies D L, Savory H N, Boon G C, Greene K T, and Spratling M G Excavations at Abergavenny 1962-1969; I. Prehistoric and Roman finds, The Monmouthshire Antiquary 2 (4): 163-198.

Timby J (1998) Excavations at Kingscote and Wycomb, Gloucestershire. Cirencester: Cotswold Archaeological Trust.

Van Arsdell R D (1989) Celtic Coinage of Britain. London: Spink.

Van Arsdell R D (1992) Money, supply and credit in Iron Age Britain. In: M Mays (ed) Celtic Coinage: Britain and Beyond. The Eleventh Oxford symposium on coinage and monetary history. BAR British Series 222. Oxford: BAR, pp139-50.

Van Arsdell R D (1994) The Coinage of the Dobunni. Money Supply and Coin Circulation in Dobunnic Territory. Oxford: Oxford University Committee for Archaeology.

Van Arsdell R D (2007a) The Semiotics of Celtic Coinage I - Rudings Challenge. NCIRC 115: 206.

Van Arsdell R D (2007b) Semiotics of Celtic Coins II - Circumstance Selectors. NCIRC 115: 259.

Van Arsdell R D (2008a) Semiotics of Celtic Coins III - Amalgamation Switchers. NCIRC 116: 4.

Van Arsdell R D (2008b) Semiotics of Celtic Coins IV - Extensions into the Continuum. NCIRC 116:124. 
Van Arsdell R D (2008c) Semiotics of Celtic Coins V - It's Not Art. NCIRC 116: 195.

Van Arsdell R D (2009a) Semiotics of Celtic Coins VI - Cunobeline's Ship. NCIRC 117:11.

Van Arsdell R D (2009b) Semiotics of Celtic Coins VII - The Search for Codes. NCIRC 117: 103.

Van Arsdell R D (2010a) Semiotics of Celtic Coins VIII - Seeing Past the Die-Cutters. NCIRC 118: 13.

Van Arsdell R D (2010b) Semiotics of Celtic Coins IX - The Minefield of Metaphor. NCIRC 118

Van Arsdell R D (2015a) Semiotics of Celtic Coins X - Inventions, Replicas and Applying the Brakes. [online] http://www.vanarsdellcelticcoinageofbritain.com/coin_articles/v2015e.html Date Accessed 14/12/2015.

Van Arsdell R D (2015b) Semiotics of Celtic Coins XI - Producing and Interpreting Replicas. [online] http://www.vanarsdellcelticcoinageofbritain.com/coin_articles/v2015f.html Date Accessed 14/12/2015.

Van Arsdell R D (2015c) Semiotics of Celtic Coins XII - Mapping Replicas. [online] http://www.vanarsdellcelticcoinageofbritain.com/coin_articles/v2015g.html Date Accessed 14/12/2015. 
Wainwright G J (1979) Gussage All Saints. An Iron Age Settlement in Dorset. DoE Archaeological Report 10. London: Department of the Environment.

Watts L and Leach P (1996) Henley Wood, Temples and Cemetery. Excavations 1962 1969 by the late Ernest Green and others. CBA Research Report 99. York: Council for British Archaeology.

Wedlake W (1982) The excavations of the shrine of Apollo at Nettleton, Wiltshire, 1956-1971. Report of the Research Committee of the Society of Antiquaries of London 40. London.

Wellington I (2006) The role of Iron Age coinage in archaeological contexts. In P de Jersey (Ed) Celtic coinage: new discoveries, new discussion. Oxford BAR International Series, pp 81-96.

Willserslev R (2007) Soul Hunters: Hunting, Animism, and Personhood among the Siberian Yukaghirs. Berkeley: University of California Press.

Williams M and Creighton J (2006) Shamanic practices and trance imagery in the Iron Age. In: De Jersey P (Ed) Celtic Coinage: New Discoveries, New Discussion. Oxford: BAR International Series, pp 49-59.

Wilson B (1999) Displayed or concealed? Cross cultural evidence for symbolic and ritual activity depositing Iron Age animal bones. Oxford Journal of Archaeology 18(3), pp297-306.

Woodward A and Leach E (1993) The Uley Shrines. Excavation of a ritual complex on West Hill, Uley, Gloucestershire: 1977-9. London: English Heritage 
